\title{
Large-scale monitoring of freshwater bivalves: an eDNA point of view on species distribution and conservation
}

\author{
Vincent Prié ${ }^{1}$, Manuel Lopes-Lima ${ }^{2}$, Pierre Taberlet ${ }^{3}$, Alice Valentini ${ }^{4}$, Nicolas Poulet ${ }^{5}$, \\ Pauline Jean ${ }^{4}$, Emilie Breugnot ${ }^{5}$, Stéphanie Couprie ${ }^{5}$, Gaëlle Jardin ${ }^{5}$, Nicolas Roset $^{5}$, \\ Thibault Vigneron ${ }^{5}$, Florent Lamand ${ }^{5}$, Olivier Gargominy ${ }^{1}$, Mathieu Rocle ${ }^{6}$, and Tony \\ Dejean $^{7}$
}

\author{
${ }^{1}$ Museum National d'Histoire Naturelle \\ ${ }^{2}$ University of Porto \\ ${ }^{3}$ Université Joseph Fourier \\ ${ }^{4}$ SPYGEN \\ ${ }^{5}$ Office Français de la Biodiversité \\ ${ }^{6}$ Compagnie Nationale du Rhône \\ ${ }^{7}$ Spygen
}

May 7, 2020

\begin{abstract}
The analysis of environmental DNA (eDNA) allows efficient surveys of freshwater species and is being increasingly used. However, most studies generally have a limited sampling plan. Because different methods are used by different authors, all the data produced with eDNA cannot be easily pooled together for a global overview. Nevertheless, one of the promising perspectives is the standardization of the methods and protocols, for long-term monitoring, early detection of invasive species, and rare species detection. We here present the biggest dataset using eDNA metabarcoding with standardized methods for freshwater bivalves. Sampling was performed mainly in France, with over 350 localities spread over all major basins. Metabarcoding was performed using two new sets of primers, one for the Unionida and one for the Venerida. The species distributions inferred from eDNA sampling are then compared with those currently known. Results give an insight into the valuable data that eDNA analysis can provide if used at a large scale. Some species were found outside of their known range, especially invasive species but also species of conservation interest. Others were found in a surprisingly low number of localities, although currently considered widespread and of no conservation interest. This can be explained by the databases currently used to establish conservation status, which are often biased by including ancient data, shell-only data, and potentially misidentified species. The present study shows that our eDNA metabarcoding approach will be an essential tool to unveil the true species distributions, to better evaluate their status and improve conservation policymaking.
\end{abstract}

\section{INTRODUCTION}

Traditionally, most freshwater mollusks inventories were based on shells records (ex. Duncan, 2008). The durability of shells may be an advantage for species detection but may lead to potential biases. Although shell surveys are less time consuming, they often overestimate population sizes, given that there is always more dead than alive specimens. More importantly, they can also be misleading regarding species occurrences. We have many examples of species being extirpated from a site where shells can still be found for many years. Furthermore, the traditional classification of freshwater mollusks is based on plastic shell traits that make identification difficult without taxonomical expertise. This turns surveys based on shells only a difficult task for some species and a source of numerous species misidentifications. This is especially true for large 
and conspicuous species such as the Unionoid bivalves. For smaller shells, like the fingernail clams, another important bias in rivers, although poorly documented, is shell drifting, where shells can be collected far away from their source population.

Therefore, most freshwater mollusks atlases based on these classical surveys are likely biased. In these publications, misidentified specimens, ancient data, and shell-only data are pooled together generally leading to enlarged species distributions and improved freshwater mollusks conservation status. Our results based on a large-scale environmental DNA (eDNA) investigation shine a light on these biases and contribute to more reliable species occurrences and therefore to more accurate conservation status assessments.

DNA barcodes provide more reliable species identifications than shell morphology (Prié, Puilandre, \& Bouchet, 2012; Prié \& Puillandre, 2014; Riccardi et al., 2019). DNA analyses are sometimes used to confirm protected species determination, e.g. for the Thick-shelled River MusselUnio crassus Philipsson, 1788, a protected species in European countries, which is sometimes difficult to identify but may have important economic impacts, if found in an area planned for project development. However, several difficulties hamper the use of DNA barcodes for species identification, among which lab availability, price, permits to sample protected species, as sampling tissue for DNA can be hazardous for mollusks, and the need to find and collect live specimens, which can be a difficult and time-consuming task. Freshwater mollusks are hard to survey, sometimes difficult to detect, especially for small species or species that spend most of their life buried. Freshwater bivalves surveys often involve scuba diving, which means having specialized biologists, costly equipment, and also increased associated risks (e.g. navigation, drifting objects, deadwood, fishing lines, etc...) which have to be accounted for, especially in a professional context.

The development of non-invasive genetic monitoring methods with the extraction of environmental DNA (eDNA) from indirect sources, such as fur, scats, or soil and water samples, brought important advances in the remote detection and monitoring of species that are rare and/or difficult to capture or sample (Taberlet, Coissac, Hajibabaei, \& Rieseberg, 2012). eDNA metabarcoding analyses are therefore a promising way to overcome the difficulties regarding freshwater mollusks' surveys and sampling. They rely on a barcoding approach, which secures determinations. Samples can be easily and safely collected in the field (contrarily to scuba diving or river prospecting), do not require particular skills, and provide data about the extant living population, as eDNA cannot be detected for long in freshwater (Dejean et al., 2011; Pont et al., 2018).

eDNA analyses have been developed for about 10 years to survey freshwater biodiversity (eg. amongst others Ficeola, Miaud, Pompanon \& Taberlet, 2008; Dejean et al., 2011; Taberlet et al. 2012; Darling \& Mahon, $2012 \ldots$ see Thomsen \& Willerslev, 2015 for a review). Most studies are still based on single-species detection and generally have a limited sampling plan (e.g., Goldberg, Sepulveda, Ray, Baumgardt, \& Waits, 2013; Evans et al., 2015; Stoeckle, Huehn, \& Geist, 2016; De Ventura, Kopp, Seppälä, \& Jokela, 2017; Klymus, Marshall, \& Stepien, 2017). Here, we present the first extensive dataset using standardized eDNA metabarcoding protocols for freshwater bivalves surveys, at the scale of whole France, with about 350 sampling sites. The present results reveal some inaccuracies in our previous knowledge of species distributions. As the extent and changes in distribution are one of the main parameters used for species conservation status assessments, this change of paradigm may have a strong impact on future conservation policies.

\section{MATERIAL AND METHODS}

The methods are described in extenso in Prié et al. (2020). We will only provide here the main points that are necessary to properly understand the significance of the results.

\subsection{Sampling}

Sampling was carried out between 2015 and 2019, mainly in summer months, between May and October, focusing on rare species and under-sampled locations to cover most of the main French watersheds. The water filtration was performed using a Vampire Sampler (Bürkle GmbH), a $0.45 \mu \mathrm{m}$ VigiDNA filtration capsule (Spygen), and disposable sterile tubing for each sample. The water was filtered for about 30 minutes or until the filter of the capsule was completely saturated. The volume of filtered water varied according to 
the turbidity and was estimated to be about 30 liters when the turbidity was low. The filter capsule was emptied by injecting air, then filled with $80 \mathrm{~mL}$ of CL1 buffer (Spygen), and stored at room temperature until DNA extraction. Two eDNA samples were collected per site.

\subsection{DNA extraction}

The content of each capsule was transferred to a $50 \mathrm{~mL}$ Falcon tube that was centrifugated for 15 min at $15,000 \mathrm{~g}$. The supernatant was removed, leaving $15 \mathrm{~mL}$ of liquid. Then, alcohol precipitation was performed by adding $33 \mathrm{~mL}$ of ethanol and $1.5 \mathrm{~mL}$ of $3 \mathrm{M}$ sodium acetate were added to each $50 \mathrm{~mL}$ tube, and samples were stored for $24 \mathrm{~h}$ at $-20^{\circ} \mathrm{C}$. After centrifugation for $15 \mathrm{~min}$ at $15,000 \mathrm{~g}$, the supernatant was discarded. $360 \mu \mathrm{L}$ of ATL Buffer of the DNeasy Blood \& Tissue Extraction Kit (Qiagen) were added to the pellet, thoroughly mixed, and transferred in a $2 \mathrm{~mL}$ tube. The remaining steps of the DNA extraction were carried out using the NucleoSpin soil kit (Macherey Nagel) from step 6. The DNA was eluted with $100 \mu \mathrm{L}$ of SE buffer twice. Two types of extraction negative controls were performed during each extraction session, the first one starting with a $50 \mathrm{~mL}$ Falcon tube filled by CL1 buffer, and the second one starting with $360 \mu \mathrm{L}$ of ATL Buffer of the DNeasy Blood \& Tissue Extraction Kit (Qiagen) in a $2 \mathrm{~mL}$ tube.

\subsection{DNA amplification}

Two primer pairs were used, each amplifying either the Unionida or the Venerida (Prié et al., 2020; presented in Table 1). Each DNA extract was amplified in twelve replicates per primer pair, including all the extraction negative controls and the PCR negative controls.

The amplification mixture contained $1 \mathrm{U}$ of AmpliTaq Gold Polymerase (Applied Biosystems), 1x PCR Gold buffer containing $2 \mathrm{mM}$ of $\mathrm{MgCl} 2,0.2 \mathrm{mM}$ of each dNTPs, $0.5 \mu \mathrm{M}$ of each tagged forward and reverse primers and $0.2 \mathrm{mg} / \mathrm{mL}$ of bovine serum albumin (BSA, Roche Diagnostics). The final volume was $25 \mu \mathrm{L}$ including $3 \mu \mathrm{L}$ of eDNA extraction. All amplification underwent the same PCR parameters (initial denaturation for 3 min at $95^{\circ} \mathrm{C}, 50$ cycles of $30 \mathrm{~s}$ at $95^{\circ} \mathrm{C}, 30 \mathrm{~s}$ at $50^{\circ} \mathrm{C}$ and $30 \mathrm{~s}$ at $72^{\circ} \mathrm{C}$, and final elongation at $72^{\circ} \mathrm{C}$ for $5 \mathrm{~min}$ ). Forward and reverse primers were $5^{6}$-labeled with identical eight nucleotides tags to enable the subsequent assignment of sequences to their respective sample. Each tag had at least four differences with other tags to properly assign reads to samples. A total of 65 negative extraction controls and 35 PCR negatives controls (ultrapure water) were also included in the experiment to monitor possible contaminations. Pooled PCR products were purified using a MinElute PCR purification kit (Qiagen), with elution in $15 \mu$ l buffer.

\subsection{DNA sequencing}

A total of 43 libraries were prepared at Fasteris facilities (Geneva, Switzerland) using the Metafast protocol (www.fasteris.com/metafast). These libraries were sequenced either on Illumina HiSeq 2500 (2x $125 \mathrm{bp})$ or Illumina NextSeq (2 x 150 bp) platforms (Illumina, San Diego, CA, USA), targeting 300,000 forward and reverse reads per sample and primer pair.

\section{Sequence analysis}

The sequence analysis was done using the OBITools package (Boyer et al., 2016). Briefly, forward and reverse reads were assembled usingilluminapairedend program before assigning the assembled sequences to the different samples using the ngsfilter. The original dataset was split into several files using the obisplitprogram, one file per sample and primer pair. Sequences corresponding most likely to PCR or sequencing errors were discarded. The discarded sequences were shorter than $20 \mathrm{bp}$, or occurring less than 10 times per sample, or labeled as "internal" by the obiclean program. The taxonomic assignment was carried out with the ecotag program, using a curated reference database (Prié et al. 2020) or a database extracted from the EMBL release 138. Only sequences with a similarity higher than $98 \%$ with one of the databases were kept. All sequences with a frequency of occurrence below 0.001 were considered as potential tag-jumps (Schnell, Bohmann, \& Gilbert, 2015) and discarded.

\subsection{Available freshwater bivalves data for France}


In order to compare the data collected with freshwater bivalves eDNA metabarcoding, data provided by INPN were used. INPN (Inventaire national du Patrimoine naturel, National Inventory of the NAtural Heritage) is a system implemented to ensure in a standardized way the restitution of synthetic data needed for the expertise, the development of conservation strategies and the dissemination of information and national and international reports relatied to the French natural heritage (plant and animal species, natural habitats and geological heritage, seehttps://inpn.mnhn.fr/accueil/presentation-inpn?lg=en, and Gargominy, Léonard, Prié and Cucherat, 2016). The information comes from many national programs and data provided by various partners. INPN ensure the validation of this data on three levels (1) conformity, e.g. the species is referenced in the French taxonomic register (Gargominy et al., 2019) and the observation is situated in France; (2) consistency, e.g. observation is not dated after the integration of the data; (3) scientific validation, e.g. marine species is not recorded on land.

INPN thus includes data provided in the literature (grey as well as academic), in museum collection as well as observations through various programs. About 32900 freshwater bivalve data are available on the INPN database in 2020. For focused species of conservation concern, the Giant Freshwater Pearl Mussel Pseudunio auricularius (Spengler, 1793), the Depressed River Mussel Pseudanodonta complanata (Rossmässler, 1835), the Nut Orb Mussel Sphaerium rivicola (Lamarck, 1818) and the Witham Orb Mussel S. solidum (Normand, 1844), a distinction was made between ancient data (i.e. here data collected before the year 2000) and recent ones. Shell-only data were considered as ancient data.

\section{RESULTS}

\subsection{Freshwater bivalves biodiversity pattern}

Each water sample yielded on average 8.1 species (ranging from 0 to 24 species, distribution showed in Figure 1). In only three water samples no bivalve at all could be detected. It was always in still waters, in small pounds. Sites with only one species were either in pounds, or close to the sea (hence possibly brackish), or high upstream the hydrosystem. On the other hand, the richest sites ( 15 species and over) were always large rivers as shown in Figure 2. Half of the sites had between 5 and 11 species.

\subsection{Focus on species}

Our results are broadly congruent with the known distribution of the French freshwater bivalve species (Prié, 2017). However, some species were detected out of their known distribution range, noticeably introduced and invasive species, but not only. Others were not detected where they were expected, and valuable data was collected about poorly known species.

\subsubsection{Out-of-range species}

Outstanding data has been collected with eDNA for conservation-concerned species, such as the Thick-shelled River Mussel U. crassus (categorized EN by the IUCN and listed in the European habitat directive annex II). The Thick-shelled River Mussel is widespread in the basins of the Loire, Saône, Seine, and generally speaking in the north-eastern half of France as shown in Figure 3a. Although its populations have largely declined over the last century (Lopes-Lima, Kebapçı, \& Van Damme, 2014), there are many recent records of living populations throughout its range. On the other hand, the species was not known south of the Loire catchment area on the Atlantic coast (except for a few specimens in museum collections from the Dordogne with doubtful vouchers, unpublished data) and historical records downstream of the Rhône catchment area have not been updated despite intensive research in the Camargue wetland and Ardèche River. Data collected by eDNA analysis confirmed the presence of the species throughout the north-eastern quarter of its range and revealed its presence (i) upstream of the Dordogne and Charente watersheds, south of the Loire drainage, where field surveys confirmed its presence by the observation of a few live individuals in 2018 and 2019, and (ii) in several sectors of the Rhône River mainstream, particularly downstream, where it was not known from recent data.

The Rhône River is one of the largest European rivers. The lower Rhône, not surprisingly, remains a terra incognita for the malacologist. It is a large, fast-flowing, deep, turbid, navigated river that is very hard 
to sample. No scuba-diving nor extensive dredging campaign has been performed to investigate freshwater bivalves species. The lower Rhône flows in the Mediterranean area, and its valley constitutes a northward extension of the northwestern Mediterranean subregion (ex. Darwall et al., 2014). Its tributaries in the lower part are typical Mediterranean streams on its right bank and rather alpine streams on its left bank. Hence its tributaries, which are easier to sample, are very different ecosystems from the Rhône itself. While the Rhône valley allows a northward extension of the Mediterranean biome, the Rhône itself provides a southward path for species of more northern affinities such as the Thick-shelled River Mussel and the Swollen River Mussel U. tumidus Philipsson, 1788. These new data could justify the implementation of conservation measures (Natura 2000 network in particular) on new stretches of the river.

Species of the genus Anodonta are sometimes difficult to identify and are probably often misidentified in databases. Because these species are widespread and common, validation processes of databases do not focus on these potential misidentifications. In many cases, a barcoding approach is needed to clarify the Anodonta populations' taxonomic status. As an example, the Italian Swan Mussel Anodonta exulcerata Porro, 1838 has been recently re-described in Italy, based on molecular data (Froufe et al., 2017). There is no reliable diagnostic morphological character to identify it in the field (Riccardi et al., 2019). It was considered endemic to Italy and Switzerland. In this study, eDNA sequences of the species were detected in a few places in the upper Loire River. The Italian Swan Mussel is a new species for France, maybe introduced from Italy. It would for sure have been overlooked without an eDNA highlighting.

\subsubsection{Invasive species}

The Chinese Pond Mussel Sinanodonta woodiana (Lea, 1834) is a large species, introduced in France since 2007, which has rapidly spread in the south of France and the Rhone basin (Adam, 2010). Data collected by eDNA analysis confirmed the expansion of this easily identifiable species in the field, and add a few localities that were not previously known: downstream of the Tarn River, confirming the rapid colonization of the Garonne basin, the Sèvre niortaise River, from where it has since been observed with traditional methods, the Saône River, where it had not been detected during the freshwater bivalves surveys carried out in 2016 by scuba-diving, and the Moselle River. On the other hand, eDNA analyses show that it is probably still absent from the Meuse and Dordogne watersheds, where the eDNA observation pressure is high, and apparently from the Adour, Seine and Charente basins. For all these basins, it would be urgent to implement protection measures to avoid the colonization of the Chinese Pond Mussel. Indeed, it is now known that this species represents a significant threat to native species (Donrovich et al., 2017; Huber \& Geist, 2019).

The Quagga Mussel Dreissena rostriformis bugensis (Andrusov, 1897) is a smaller species, similar in shell shape to the widespread Zebra mussel Dreissena polymorpha (Pallas, 1771), and therefore likely to remain unnoticed due to confusion or negligence. It has only been known in France since 2010 when it was first detected in the Meuse and Moselle basins (Bij de Vaate \& Beisel, 2011). According to previously available data shown in Figure 3b, it was thought to have colonized only the Meuse and Moselle Rivers, with scattered data in the Rhine and Rhône Rivers (Prié \& Fruget, 2017). eDNA data shows that the species has already spread considerably, being also introduced into the Mediterranean coastal rivers (Lez River in Montpellier, probably via the Bas-Rhône-Languedoc Canal), and into the Seine watershed (probably via the Canal de Bourgogne), where it had never been observed with traditional surveys. None of our samples from the Atlantic drainages contained Quagga Mussel eDNA. These results highlights the value of eDNA sampling for invasive species' early detection and monitoring.

The Ridgedbeak Peaclam Euglesa compressa (Prime, 1852) has been formally discovered in France very recently (Mouthon \& Forcellini, 2017), although the first data on its distribution date from 1989 (Mouthon \& Taïr Abacci, 2012). Analysis of the eDNA has extended its current range, with new data in the Meuse, upstream of the Seine, the Saône, the Ardèche, and all along the lower Rhône River.

\subsubsection{Rare and endangered species}

Our large-scale sampling in France stressed out the worrying conservation status of some species which are not currently considered of conservation concern. The Depressed River Mussel P. complanatahistorically 
had a wide distribution in France, as evidenced by museum collections (especially those of the National Museum of Natural History in Paris, unpublished data), where three subspecies were recognized (Bouchet, 2002). About a hundred records are available in France (see Figure 3c). Out of these, 46 concern individuals observed living recently. These data attest to the presence of the species in the catchment areas of the Seine (about 15 stations), the Somme (one station), the Meuse (two stations), the Moselle (one station) and the Rhine (one station). There is no recent record of live specimens elsewhere in France. eDNA data confirm the current presence of the species in the Seine, the Meuse (9 stations out of the 52 sampled), the Moselle (only one station studied), but also in the Saône (one station out of the two studied), the lower Rhône (only one station out of the 65 sampled) and the Charente (only one station out of the 7 analyzed) Rivers. Depressed River Mussel eDNA was not detected in any of the localities sampled in potentially favorable sites (downstream ecosystems on limestone substratum) in the Garonne basin. Similarly, although few favorable stations were studied on the Loire drainage, none revealed the species. The Depressed River Mussel seems to be extirpated from most of its range in France. The only data on the lower Rhône is remarkable, as no historical data are known for this sector.

The Witham Orb Mussel Sphaerium solidum is a typical downstream species, living in large rivers, at depth, in well-oxygenated water, preferably on sandy substrates. This kind of environment has been extensively sampled in our study (estimated 250 sampling sites suitable to the Witham Orb Mussel), but the Witham Orb Mussel has been detected only once in our samples, close to one of the three places where it has been last observed alive. Comprehensive data is available given its easily identifiable thick shell, which can be preserved for years in the river banks as shown in Figure 3d. But this data, mainly based on shell observations, probably give an obsolete picture of the reality. According to eDNA results, the Witham Orb Mussel appears to be extirpated from the Aisne site by now (where sampling occurred about 10 years after its observation). Only a single population would remain, in the lower Seine, which makes the Witham Orb Mussel the most threatened freshwater bivalve species in France.

The Nut Orb Mussel S. rivicola is also a species characteristic of downstream large rivers, probably less demanding in terms of the substrate than the Witham Orb Mussel, preferring more muddy sediments. It also seems a little less threatened, but its situation concerning eDNA sampling throughout France is alarming. About a hundred records are available, spread over most of the large French catchment areas. Nevertheless, very few living populations are currently known. At least one population seems to subsist downstream of the Loire, on a sector that we did not sample in the framework of this work. eDNA was only detected in a single site in the Rhône catchment (out of 65 sampled sites) eDNA could be detected indicating that Nut Orb Mussels still occurs there, but probably with very poor conservation status since it is not known elsewhere in the basin. Living individuals have recently been collected on the Meuse River, data confirmed by eDNA analysis. Finally, there are several recent records of living individuals in the Seine basin, but the eDNA sampling revealed the species only once in the Seine basin, closed to a previously reported living population.

The False Orb Pea Mussel Euglesa pseudosphaerium Favre, 1927 is a lowland rivers species that lives on stable swampy areas, in clear and clean waters and is intolerant to pollution and water level fluctuations (Welter-Schultes 2012). This kind of habitat has become very rare in France, and so is the False Orb Pea Mussel. Welter-Schultes (2012) gives it a wide distribution range, covering most of France, although it is rare and localized everywhere. Mouthon and Kuiper (1987) recorded it from only four sites in the Rhone Valley and report an additional historical record near Toulouse (south-west France). Despite extensive sampling, we didn't detect its eDNA in the Rhone Valley. It has been detected with eDNA analyses once in a small tributary of the Charente River and once in Britany (north-west France). Although suitable habitat for this species is under-sampled, eDNA data confirm the worrying conservation status of the False Orb Pea Mussel.

\section{DISCUSSION}

\subsection{Standardized eDNA sampling at a large scale}

For the first time here, we have implemented eDNA surveys at a large scale, with standardized sampling protocols and analyses. Our results are therefore comparable, both in space and time: it is now possible to 
reproduce our sampling in the future to monitor the evolution of bivalve populations. This is particularly relevant for monitoring invasive species: eDNA analyses are usually used to detect a given species' occurrence. But it can also be used to argue for absence. Our large-scale eDNA sampling revealed the occurrence of invasive species in their previously known range and also in locations they were expected to colonize considering the potential colonization routes (i. e. mainly artificial channels connecting main watersheds, eg. Prié \& Fruget, 2017). Contrarily, eDNA samples confirm the absence of the invasive species where they were not (yet) expected. Re-sampling these places regularly could allow documenting colonization. Our results also confirm that some introduced species are not invasive. For example, the Long Fingernail Clam Sphaerium transversum (Say, 1829) has been recorded only twice in France with traditional methods, and eDNA only added one isolated data.

On the other hand, large-scale eDNA sampling was valuable to detect rare and endangered species. The False Orb Pea Mussel was detected in only two sites in France, supporting its critical conservation status. Only one new location could be added by our eDNA samples for the very well-known Giant Freshwater Pearl Mussel (Prié et al., 2018). Furthermore, some species such as the Depressed River Mussel, the Nut Orb Mussel, and above all the Witham Orb Mussel were rarely detected despite their supposed large distribution range in France, which flashes a red light on their conservation status.

\subsection{Limits of molecular taxonomy and eDNA perspectives}

Our results are still potentially biased by the uncertainties of molecular taxonomy. It is not clear whereas our species delimitations, mainly based on mitochondrial DNA (mtDNA) markers, actually reflect species boundaries.

First, do the mtDNA markers used to characterize species reflect species boundaries? This question has already been addressed for French Naiad species by Prié and Puillandre (2014), but the status of the species within the "pictorum" group, i.e. for France U. mancusLamarck, 1819 and U. pictorum (Linnaeus, 1758), and within the "crassus" group, i.e. for France U. crassus crassusPhilipsson, 1788 and U. c. courtillieri (Hattemann, 1859) remains unsolved. From our database U. mancus and U. pictorum, as defined by mtDNA molecular markers, seem to largely overlap geographically - and are not discriminable neither from shell shape nor anatomy where both lineages are sympatric. Their mtDNA divergence may only result from ancestral polymorphism retention, and these two species may be synonyms. The least that can be said is that eDNA large scale sampling results in France, together with field experience, do not argue in favor of two distinct species.

Regarding the Thick-Shelled River Mussel U. crassus (a species having Doubly Uniparental Inheritance, Significance Box 1), mtDNA female marker would argue in favor of distinct species, namely U. crassus and U. courtillieri. Mioduchowska, Kaczmarczyk, Zajac and Zajac (2016) showed that an independent marker, identified in male mtDNA, also reveals two distinct lineages with a significant divergence. But for now, there is no evidence that these two independent markers tell the same story in any sampled specimen: these two lineages may largely interbreed and mt DNA may just bear the scars of a complex phylogeography with multiple species contractions and expansions throughout the glacial ages. We decided not to distinguish these two taxa in our eDNA protocol.

Hybridization and the hazards of molecular taxonomy have been largely documented for the Asiatic Clams Corbicula spp. (Pfenninger, Reinhardt, \& Streit, 2002; Pigneur et al., 2011). Here, we did not distinguish the three species described for France (C. fluminea(O.F. Müller, 1774), C. fluminalis (O.F. Müller, 1774) and C. leana Prime, 1867, sensus Pigneur et al. 2011), although one haplotype of $C$. fluminalis seems to be proper to this species. eDNA large-scale analysis makes it possible to map the different haplotypes of this species complex, and maybe provide insights for a better understanding of invasive species colonization routes.

Second, the haplotype diversity of each species is not known. We have only a few sequences for most of the species, sometimes only one specimen studied for the $16 \mathrm{~S}$ gene (eg. the Iridescent Pea MusselE . pulchella (Jenyns, 1832) or the Oval Orb MusselS. ovale (A. Férussac, 1807), see Supporting information). And yet, some of the short fragments we amplify with our primers are haplotypes shared between different species 
(Prié et al., 2020). Therefore, it is not sure if the various haplotypes detected reflect species distribution or are shared between unknown species. For example,E. pulchella is known from only one $16 \mathrm{~S}$ sequence, which is closely related to the haplotypes of the Short-ended Pea Mussel E. subtruncata (Malm, 1855) (seven known haplotypes of our short $16 \mathrm{~S}$ fragment). If the haplotype referenced as E. pulchella in our reference library was also a rare haplotype of E. subtruncata, the distribution given here for E. pulchella could be heavily biased. What we present here is haplotypes distribution.

But eDNA remains an interesting tool to investigate genetic diversity in the field. In that respect, the samples performed in Morocco and Italy allowed characterizing male mtDNA of The Moroccan River MusselUnio foucauldianus Pallary, 1936 and the Italian River Mussel U. elongatulus C. Pfeiffer, 1825, and in Morocco, many previously unknown haplotypes of the Caserta Pea Mussel E. casertana (Poli, 1791) were amplified.

\subsection{Conclusion}

According to eDNA data, downstream ecosystems are the most species-rich. They are also the most threatened, facing diffuse and cumulated threats from upstream, and located in the most human-impacted areas (populated areas, agricultural plains, industrial effluents...). Our eDNA results highlight very important conservation issues for species downstream of major rivers. In a context of biodiversity erosion and declining populations sizes, it seems essential to implement consistent conservation policies for downstream species, which are currently insufficiently considered by naturalists and managers alike due to the difficulty of access to these environments.

eDNA analyses, with an optimal protocol, have the potential of providing not only "presence", but also "absence" data. Using standardized methods it becomes now possible to reliably document both the progression of invasive species, as well as range contractions of endangered species. Large-scale and long-term eDNA metabarcoding surveys clearly represent a valuable tool for preserving and monitoring freshwater bivalves. However, regarding the poorly known species, it should be kept in mind that what we present here is $16 \mathrm{~S}$ haplotypes distribution. They may not reflect the actual distribution of species as further studies may jeopardize the current state-of-the-art of molecular taxonomy. This is just an eDNA point of view.

\section{Acknowledgements}

The development of the eDNA analysis method for bivalves was carried out jointly by Caracol NGO, Spygen company and Biotope consultancy. The Office Français de la Biodiversité and the Direction Régionale de l'Environnement, de l'Aménagement et du Logement d'Occitanie contributed to its financing. The data presented here includes work carried out by Biotope and Aquascop consultancies, Caracol NGO, SpyGen, the Compagnie Nationale du Rhône, the Regional Natural Park of Limousin, the Conservatoires d'Espaces Naturels Midi-Pyrénées and Nouvelle Aquitaine, the LIFE + Giant Freshwater Mussel program, GRT Gaz, Voies Navigables de France, EPTB Vilaine, CPIE Loire-Anjou for the main studies. The DREAL Grand Est, Nouvelle Aquitaine, Occitanie and the DDT du Tarn also financed part of the studies. We would also like to thank all those who participated in the sampling and laboratory analysis of the samples, in particular Pascal Irz (OFB), Laurent Philippe (Biotope), Mathieu Saget (Aquascop), Mathieu Charneau (OFB).

This research was also developed under ConBiomics: the missing approach for the Conservation of Freshwater Bivalves Project No NORTE-01-0145-FEDER-030286, co-financed by COMPETE 2020, Portugal 2020 and the European Union through the ERDF, and by Portuguese Foundation for Science and Technology (FCT) through national funds.

\section{References}

Adam, B. (2010). L'Anodonte chinoise Sinanodonta woodiana (Lea, 1834) (Mollusca, Bivalvia, Unionidae) : une espèce introduite qui colonise le bassin Rhône-Méditerranée. MalaCo , 6, 278-287.

Bij de Vaate, A., \& Beisel J.-N. (2011). Range expansion of the quagga mussel Dreissena rostriformis bugensis (Andrusov, 1897) in Western Europe: first observation from France. Aquatic Invasions,6(Suppl. 1), 71-74. doi: 10.3391/ai.2011.6.S1.016 
Bouchet, P. (2002). Mollusques terrestres et aquatiques de France: un nouveau référentiel taxonomique, un nouveau départ, de nouvelles perspectives. In G. Falkner, Th. E. J. Ripken, \& M. Falkner (Eds.), Mollusques continentaux de France; liste de référence annotée et bibliographie (pp. 5-20). Paris, Patrimoines Naturels 52.

Boyer, F., Mercier, C., Bonin, A., Le Bras, Y., Taberlet, P., \& Coissac E. (2016). obitools: a unix-inspired software package for DNA metabarcoding. Molecular Ecology Resources, 16, 176-182. doi: 10.1111/17550998.12428

Breton, S., Doucet-Beaupré, H., Stewart, D., Hoeh W., \& Blier, P. (2007). The unusual system of doubly uniparental inheritance of mtDNA: Isn't one enough? Trends in genetics, 23, 465-74. doi: 10.1016/j.tig.2007.05.011.

Darling, J. A., \& Mahon, A. R. (2011). From molecules to management: Adopting DNA-based methods for monitoring biological invasions in aquatic environments. Environmental Research, 111, 978-988. doi: 10.1016/j.envres.2011.02.001

Darwall, W., Carrizo, S., Numa, C., Barrios, V., Freyhof, J., \& Smith, K. (2014). Freshwater Key Biodiversity Areas in the Mediterranean Basin Hotspot: Informing species conservation and development planning in freshwater ecosystems. Retrieved from IUCN website: https://portals.iucn.org/library/sites/library/files/documents/SSC-OP-052.pdf. doi: 10.2305/IUCN.CH.2014.SSC-OP.52.en.

Dejean, T., Valentini, A., Duparc, A., Pellier-Cuit, S., Pompanon, F., Taberlet, P., \& Miaud, C. (2011). Persistence of environmental DNA in freshwater ecosystems. PLoS ONE, 6, e23398. doi: 10.1371/journal.pone.0023398

De Ventura, L., Kopp, K., Seppälä, K., \& Jokela, J. (2017). Tracing the quagga mussel invasion along the Rhine river system using eDNA markers: early detection and surveillance of invasive zebra and quagga mussels. Management of Biological Invasions, 8, 101-112. doi: 10.3391/mbi.2017.8.1.10

Donrovich, S., Douda, K., Plechingerova, V., Rylková, K., Horky, P., Slavík, O., Huan-zhang, L., Reichard, M., Lopes-Lima, M., \& Sousa, R. (2017). Invasive Chinese pond mussel Sinanodonta woodianathreatens native mussel reproduction by inducing crossresistance of host fish. Aquatic Conservation Marine and Freshwater Ecosystems , 1-9. doi: 10.1002/aqc.2759.

Duncan, N. (2008). Survey Protocol for Aquatic Mollusk Species: Preliminary Inventory and Presence/Absence Sampling, Version 3.1. Portland, OR. Interagency Special Status/Sensitive Species Program. U.S. Department of Interior, Bureau of Land Management, Oregon/Washington and U.S. Department of Agriculture, Forest Service, Region 6. Retrieved from https://www.blm.gov/or/plans/surveyandmanage/files/10-mollusks_v3-1.pdf

Evans, N. T., Olds, B. P., Turner, C. R., Li, Y., Jerde, C. L., Mahon, A. R., Pfrender, M. E., Lamberti, G. A., \& Lodge, D. M. (2015). Quantification of mesocosm fish and amphibian species diversity via eDNA metabarcoding. Molecular Ecology Resources , 16, 29-41. doi: 10.1111/17550998.12433

Ficetola, G. F., Miaud, C., Pompanon, F., \& Taberlet, P. (2008). Species detection using environmental DNA from water samples.Biological Letters, 4, 423-425. doi: 10.1098/rsbl.2008.0118

Froufe, E., Lopes-Lima, M., Riccardi, N., Zaccara, S., Vanetti, I., Lajtner, J., Teixeira, A., Varandas, S., Prié, V., Zieritz, A., Sousa R., \& Bogan, A. E. (2017). Lifting the curtain on the freshwater mussel diversity of the Italian Peninsula and Croatian Adriatic coast.Biodiversity and Conservation, 26, 3255-3274. doi: $10.1007 / \mathrm{s} 10531-017-1403-\mathrm{z}$

Gargominy, O., Léonard, L., Prié, V., \& Cucherat, X. (2016). De l'utilité d'un inventaire national. MalaCo , $12: 67-87$. 
Gargominy, O., Tercerie, S., Régnier, C., Ramage, T., Dupont, P., Daszkiewicz, P., \& Poncet, L. (2019). TAXREF v13, référentiel taxonomique pour la France : méthodologie, mise en œuvre et diffusion. Retrieved from National Museum fop Natural History, Paris https://inpn.mnhn.fr/docs-web/docs/download/302170

Goldberg, C. S., Sepulveda, A., Ray, A., Baumgardt J., \& Waits, L. P. (2013). Environmental DNA as a new method for early detection of New Zealand mudsnails (Potamopyrgus antipodarum ). Freshwater Science, 32, 792-800. doi: 10.1899/13-046.1

Huber, V., \& Geist, J. (2019). Reproduction success of the invasiveSinanodonta woodiana (Lea 1834) in relation to native mussel species. Biological Invasions , 21, 3451-3465. doi: 10.1007/s10530-019-02060-3.

Klymus, K. E., Marshall, N. T., \& Stepien, C. A. (2017). Environmental DNA (eDNA) metabarcoding assays to detect invasive invertebrate species in the Great Lakes. PLoS ONE , 12(5), e0177643. doi:10.1371/journal.pone.0177643

Liu, H.-P., Mitton, J. B., \& Wu, S.-K. (1996). Paternal mitochondrial DNA differentiation far exceeds maternal mitochondrial DNA and allozyme differentiation in the freshwater mussel, Anodonta grandis grandis . Evolution , 50, 952-957. doi: 10.1111/j.1558-5646.1996.tb03907.x

Lopes-Lima, M., Kebapçı, U., \& Van Damme, D. (2014). Unio crassus. The IUCN Red List of Threatened Species 2014: e.T22736A42465628. doi: 10.2305/IUCN.UK.2014-1.RLTS.T22736A42465628.en. Downloaded on 28 April 2020.

Mioduchowska, M., Kaczmarczyk, A., Zajac, K., Zajac T., \& Sell, J. (2016). Gender-associated mitochondrial DNA heteroplasmy in somatic tissues of the endangered freshwater mussel Unio crassus (bivalvia: unionidae): implications for sex identification and phylogeographical studies. Journal of Experimental Zoology, 325A, 610-625. doi: $10.1002 /$ jez.2055

Mouthon, J., \& Kuiper, J. (1987). Inventaire des Sphaeriidae de France. Paris, MNHN (Collection Inventaire de Faune et de Flore).

Mouthon, J., \& Tair Abbaci, K. (2012). The taxonomic confusion surrounding Pisidium (Bivalvia, Sphaeriidae): the possible birth of a new taxon. Basteria 76 (4-6): 126-130

Mouthon, J., Forcellini, M., \& van Haaren, T. (2018). Euglesa compressa (Bivalvia, Sphaeriidae), native of North America, a 'hidden' species introduced in Western Europe before 1940. Basteria,82(1-3), 50-54.

Mouthon, J., \& Forcellini, M. (2017). Genetic evidence of the presence in France of the North American species Euglesa compressa Prime, 1852, (Bivalvia, Sphaeriidae). BioInvasions Records, 6(3), 225-231. doi : 10.3391/bir.2017.6.3.07

Mouthon, J. (2018). Répartition en France des formes actuelle et fossile d'Euglesa pulchella Jenyns , 1832 (Bivalvia, Sphaeriidae), une espèce rare. Folia conchyliologica, 45, 3-8.

Pfenninger, M., Reinhardt, F., \& Streit, B. (2002). Evidence for cryptic hybridization between different evolutionary lineages of the invasive clam genus Corbicula (Veneroida, Bivalvia). Journal of Evolutionary Biology , 15(5), 818-829. doi: 10.1046/j.1420-9101.2002.00440.x.

Pigneur, L.-M., Marescaux, J., Roland, K., Etoundi, E., Descy, J.-P., \& Van Doninck, K. (2011). Phylogeny and androgenesis in the invasive Corbicula clams (Bivalvia, Corbiculidae) in western Europe.BMC Evolutionary Biology, 11, 147. doi: 10.1186/1471-2148-11-147

Pont, D., Rocle, M., Valentini, A., Civade, R., Jean, P., Maire, A., Roset, N., Schabuss, M., Zornig, H., \& Dejean, T. (2018). Environmental DNA reveals quantitative patterns of fish biodiversity in large rivers despite its downstream transportation. Scientific Reports, 8, 10361. doi:10.1038/s41598-018-28424-8

Prie, V., Puillandre, N., \& Bouchet, P. (2012). Bad taxonomy can kill: molecular reevaluation of Unio mancus Lamarck, 1819 (Bivalvia: Unionidae) and its accepted subspecies. Knowledge and Management of Aquatic Ecosystems, 405(8). doi: 10.1051/kmae/2012014 
Prié, V., \& Puillandre, N. (2014). Molecular phylogeny, taxonomy and distribution of French Unio species (Bivalvia, Unionidae).Hydrobiologia, 735(1), 95-110. doi : 10.1007/s10750-013-1571-0

Prié, V. (2017). Naïades et autres bivalves d'eau douce de France. Mèze, Paris : Biotope éditions, Publications scientifiques du Muséum (collection Inventaires et Biodiversité).

Prié, V., \& Fruget, J.-F. (2017). Heading south: new records of the invasive freshwater quagga musselDreissena rostriformis bugensis (Andrusov, 1897) in France and further perspectives. Knowledge and Management of Aquatic Ecosystems, 418, 37. doi: 10.1051/kmae $/ 2017023$

Prié, V., Soler, J., Araujo, R., Cucherat, X., Philippe, L., Legrand, N., Patry, N., Adam, B., Jugé, P., Richard, N., \& Wantzen, K. M. (2018). Challenging exploration of troubled waters: ten years' surveys of the giant freshwater pearl mussel Margaritifera auricularia in Europe. Hydrobiologia, 818(1), 157-175. doi:10.1007/s10750-017-3456-0

Prié, V., Valentini, A., Lopes-Lima, M., Froufe, E., Rocle, M., Poulet, N., Taberlet, P. \& Déjean, T. (2020). Environmental DNA metabarcoding for freshwater bivalves biodiversity assessment: methods and results for the Western Palearctic (European sub-region). Hydrobiologia . doi: 10.1007/s10750-020-04260-8

Riccardi, N., Froufe, E., Bogan, A. E., Zieritz, A., Teixeira, A., Vanetti, I., Varandas, S., Zaccara, S., Nagel, K.-O., \& Lopes-Lima, M. (2019). Phylogeny of European Anodontini (Bivalvia: Unionidae) with a redescription of Anodonta exulcerata . Zoological Journal of the Linnean Society, zlz136. doi: 10.1093/zoolinnean/zlz136.

Stoeckle, B. C., Huehn, R., \& Geist, J. (2016). Environmental DNA as a monitoring tool for the endangered freshwater pearl mussel (Margaritifera margaritifera L.): a substitute for classical monitoring approaches? Aquatic Conservation Marine and Freshwater ecosystems, 26(6), 1120-1129. doi: 10.1002/aqc.2611

Schnell, I. B., Bohmann, K., \& Gilbert, M. T. (2015). Tag jumps illuminated - reducing sequence-to-sample misidentifications in metabarcoding studies. Molecular Ecology Resources, 15, 1289-1303. doi:10.1111/17550998.12402

Taberlet, P., Coissac, E., Hajibabaei, M., \& Rieseberg, L. H. (2012). Environmental DNA. Molecular Ecology, 21, 1789-1793. doi: 10.1111/j.1365-294X.2012.05542.x

Thomsen, P. F., \& Willerslev, E. (2015). Environmental DNA - an emerging tool in conservation for monitoring past and present biodiversity. Biological Conservation, 183, 4-18. doi: 10.1016/j.biocon.2014.11.019

Welter-Schultes, F. (2012). European non-marine molluscs, a guide for species identification. Gottingen: Planet Poster Editions.

Zouros, E., Ball, A.O., Saavedra, C., \& Freeman, K. R. (1994). Mitochondrial DNA inheritance. Nature, 368(818). doi: 10.1038/368818a0

\section{DATA AVAILABILITY}

All the data presented here is integrated (or is intended to integrate in a near future, for the OFB data) the national data base of the National Museum of Natural History, inpn. mnhn.fr.

\section{AUTHOR CONTRIBUTIONS}

Drafting of the manuscript: Prie. Critical revision of the manuscript for important intellectual content: Taberlet and Lopes-Lima. Protocol elaboration, bioinformatics and data analyses: Prie, Gargominy, Valentini, Jean and Dejean. Obtained funding: Poulet, Prie, Rocle and Dejean. Field sampling: Prie, Breugnot, Couprie, Jardin, Lamand, Roset, Vigneron. Study supervision: Prie, Lopes-Lima, Taberlet and Dejean.

Tables and Figures 


\begin{tabular}{lll}
\hline Code & Sequence 5'-3' & Reference \\
\hline Unio01_F & GCTGTTATCCCCGGGGTAR & Prié et al. 2020 \\
Unio01_R & AAGACGAAAAGACCCCGC & Prié et al. 2020 \\
Vene01_F & CSCTGTTATCCCYRCGGTA & Prié et al. 2020 \\
Vene01_R & TTDTAAAAGACGAGAAGACCC & Prié et al. 2020 \\
\hline
\end{tabular}

TABLE 1 . Codes and sequences of the primers used for amplifying environmental DNA of bivalves.

Significant Box 1

\section{Significance}

Male and female mtDNA: a particularity of some bivalve groups (including freshwater) having Doubly Uniparental Inheritance (DUI).

In bivalve species with DUI, mitochondria from the males are transferred from the spermatozoid to the egg during fecundation. Contrary to mtDNA uniparental organisms, where paternal mitochondria are immediately eliminated, in DUI bivalves, males specimens retain their father's mitochondria in their gonadal tissues, and transmit them to their offspring. This has been originally coined DUI for marine mussels (Zouros, Ball, Saavedra, \& Freeman, 1994) and firstly detected in freshwater mussels by Liu, Mitton and Wu (1996). Our eDNA primers also amplify the 16S male mtDNA fragment. Therefore, we often collect both male and female mtDNA in our samples.

\section{Hosted file}

image1.emf available at https://authorea.com/users/317031/articles/448890-large-scalemonitoring-of-freshwater-bivalves-an-edna-point-of-view-on-species-distribution-andconservation

FIGURE 1 : Distribution of the species richness among samples 


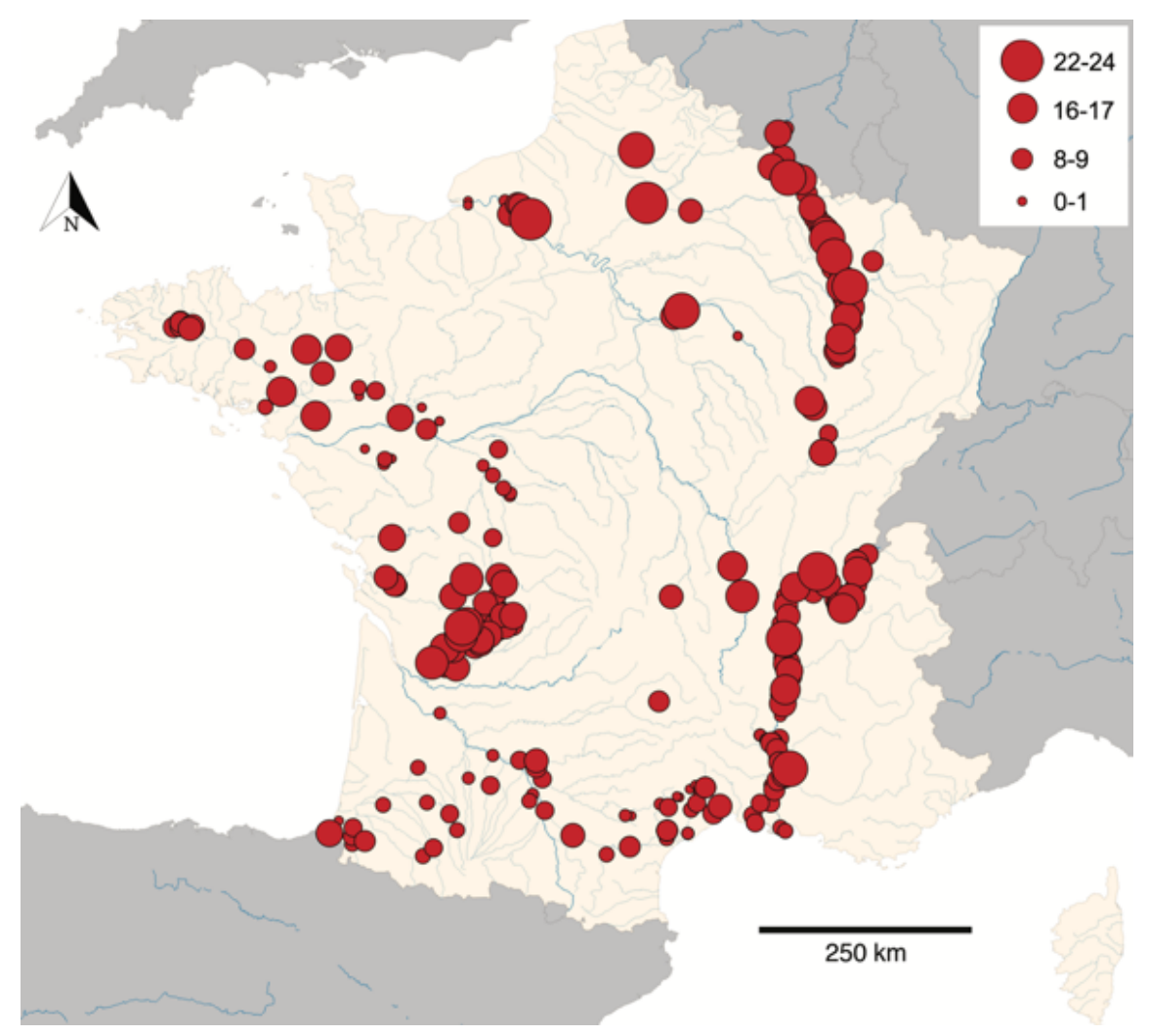

FIGURE 2 : Species' richness distribution in France. The richest sites (over 15 species per sample) are in large rivers. Most of the poorer samples are from ponds or upstream ecosystems. Dots size according to the number of species. 

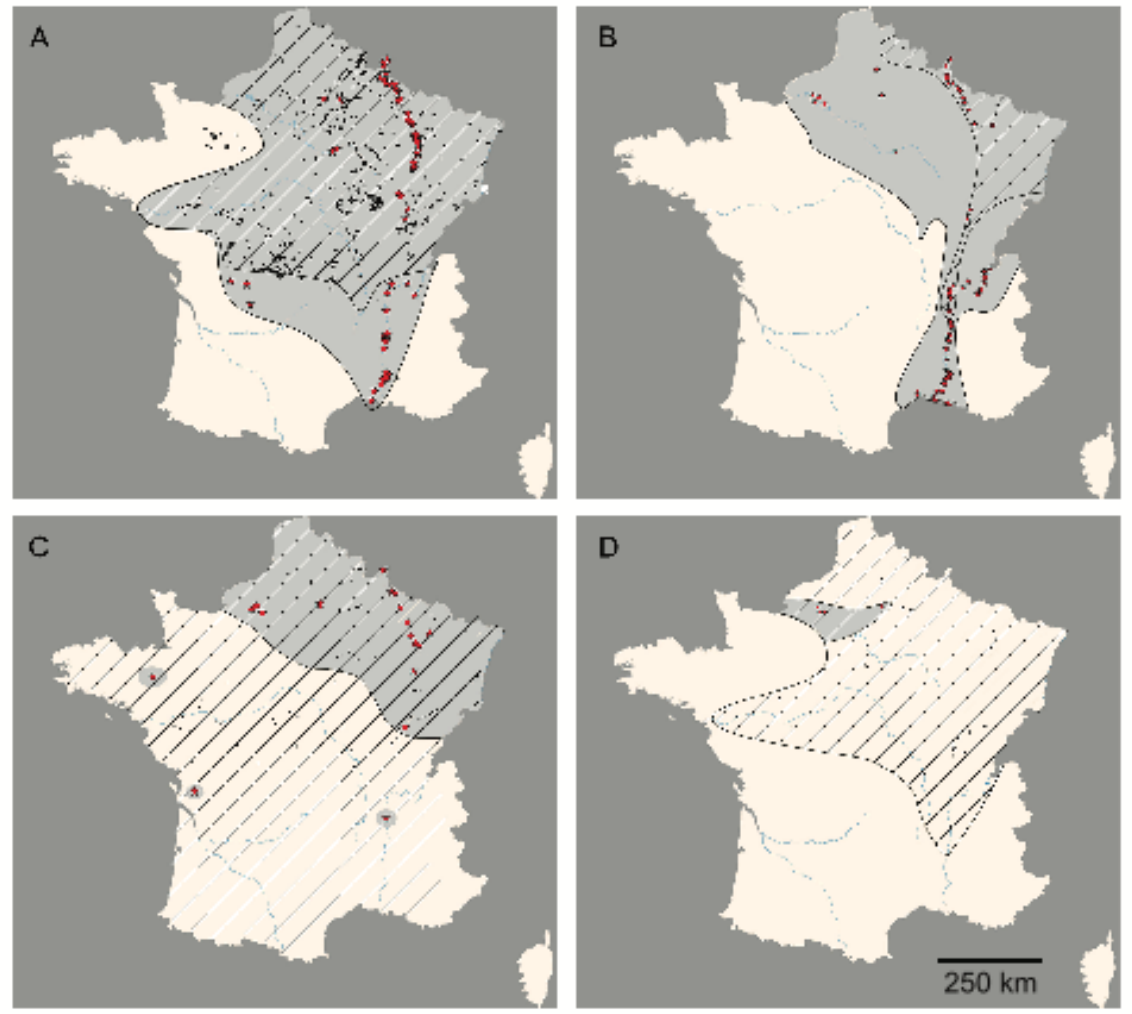

FIGURE 3 : Examples of expanding (a: Thick-Shelled River MusselU. crassus, b: Quagga Mussel D. $r$. bugensis ) and contracting (c: Depressed River Mussel P. complanata, d: Witham Orb Mussel S. solidum ) distributions inferred from our eDNA samples. Black dots: available data; red stars: eDNA data; hatched area: supposed distribution before eDNA sampling; shaded area: actual distribution range inferred from eDNA samples. eDNA absence data not shown here, for more precise maps see Supplemental Information.

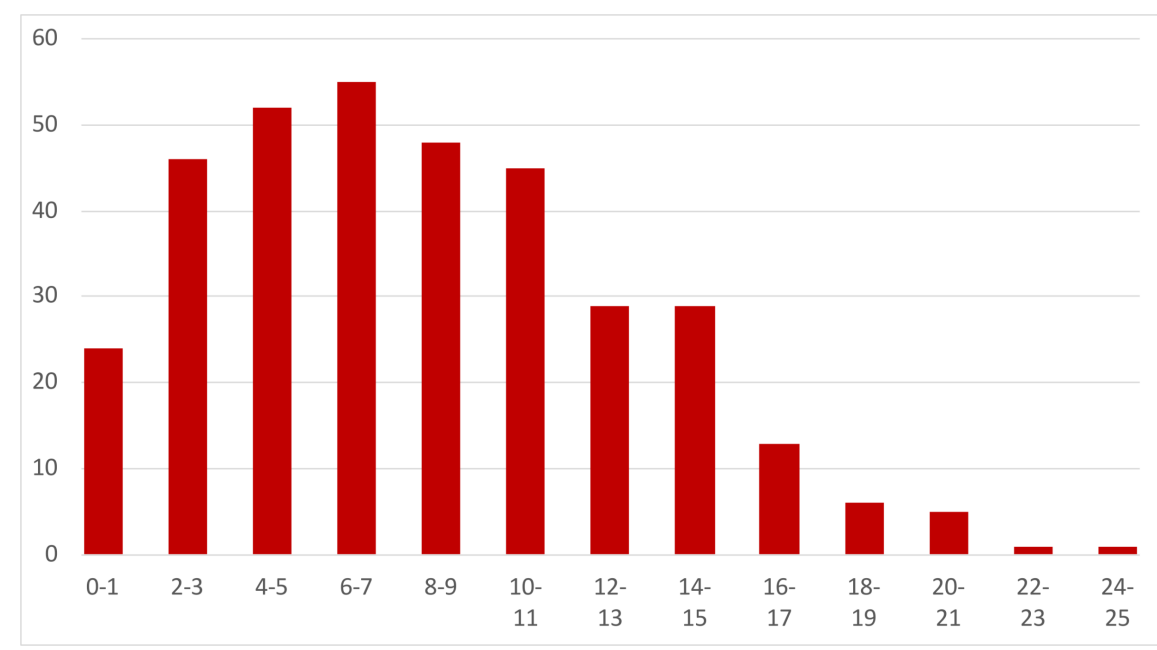

\section{Hosted file}

Fig.2_SpeciesRichness.eps available at https://authorea.com/users/317031/articles/448890- 
large-scale-monitoring-of-freshwater-bivalves-an-edna-point-of-view-on-speciesdistribution-and-conservation

\section{Hosted file}

Fig.3_Distribution.eps available at https://authorea.com/users/317031/articles/448890-largescale-monitoring-of-freshwater-bivalves-an-edna-point-of-view-on-species-distributionand-conservation

\section{Hosted file}

Table 1_Primers.docx available at https://authorea.com/users/317031/articles/448890-largescale-monitoring-of-freshwater-bivalves-an-edna-point-of-view-on-species-distributionand-conservation 